Original investigation

\title{
Genetic diversity and phylogenetic relationships in feral pig populations from Argentina
}

\author{
Diana B. Acosta ${ }^{a, b}, *$, Carlos E. Figueroa ${ }^{a, b}$, Gabriela P. Fernández $^{a}$, Bruno N. Carpinetti ${ }^{c}$, \\ Mariano L. Merino ${ }^{\mathrm{a}, \mathrm{d}}$ \\ ${ }^{a}$ Centro de Bioinvestigaciones (CeBio), Universidad Nacional del Noroeste de la Provincia de Buenos Aires (UNNOBA-CICBA)/Centro de Investigaciones y \\ Transferencia del Noroeste de la Provincia de Buenos Aires CITNOBA (UNNOBA-CONICET), Pergamino 2700, Buenos Aires, Argentina \\ b Consejo Nacional de Investigaciones Científicas y Técnicas (CONICET), CABA C1425FQB, Buenos Aires, Argentina

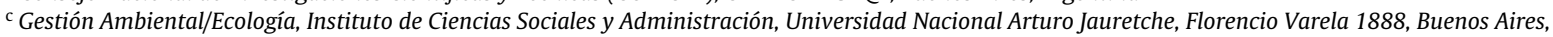 \\ Argentina \\ d Comisión de Investigaciones Científicas de la Provincia de Buenos Aires (CICPBA), La Plata 1900, Buenos Aires, Argentina
}

\section{A R T I C L E I N F O}

\section{Article history:}

Received 19 July 2019

Accepted 30 September 2019

Available online 5 October 2019

Handled by Laura Iacolina

\section{Keywords:}

Feral pig

Argentina

Control region

Amelogenin gene

Phylogenetic

\begin{abstract}
A B S T R A C T
In Argentina, domestic pigs (Sus scrofa Linnaeus 1758) were introduced during the first Buenos Aires foundation, in the year 1536. Their provenance was mainly from the Iberian Peninsula, the Canary Islands and Cape Verde. In 1541 those pigs were released and, consequently, the first feral populations were originated. Thereafter, the species propagated both naturally and through human action, reaching a distribution that covers most of the Argentinian territory. The objective of this study is to genetically characterize the oldest feral pig populations in Argentina, making use of the mitochondrial control region (CR) and the amelogenin gene (AmelY), in order to determine their phylogenetic origin and corroborate its consistency with the historic information. The obtained results indicate that most of the feral pigs in Corrientes and Buenos Aires populations are positioned in the European subclades, E1-A and E1-C for CR, and HY1 and HY2 for AmelY. Despite this fact, a low frequency of individuals of Asian origin was found in populations from Buenos Aires, whereas none of them disclosed African ancestry. Furthermore, given that a large proportion of feral pigs found in the species' original sites in Argentina have European ancestry, we can partially corroborate the historical records.
\end{abstract}

(c) 2019 Deutsche Gesellschaft für Säugetierkunde. Published by Elsevier GmbH. All rights reserved.

\section{Introduction}

Domestic pigs (Sus scrofa Linnaeus 1758) were introduced in America during Christopher Columbus' second trip to the continent in 1493, through the island La Española (currently, Republic of Haiti and Dominican Republic). These first individuals came from La Gomera Island (Canary Islands) and expanded from there towards the new Caribbean colonies and the north of South America (Donkin, 1985; Río Moreno, 1996; Zadik, 2005).

In the case of the South American Atlantic coast, the first pigs arrived in 1532, at San Vicente harbour, in what is currently the State of Sao Paulo (Brazil). They were originally from the Iberian Peninsula, the Canary Islands and Cape Verde, where the Por-

\footnotetext{
* Corresponding author at: Centro de Bioinvestigaciones (CeBio), Universidad Nacional del Noroeste de la Provincia de Buenos Aires (UNNOBA-CICBA)/Centro de Investigaciones y Transferencia del Noroeste de la Provincia de Buenos Aires CITNOBA (UNNOBA-CONICET), Pergamino 2700, Buenos Aires, Argentina.

E-mail address: dbacosta@comunidad.unnoba.edu.ar (D.B. Acosta).
}

tuguese and Spanish conquerors did their stops, prior to their arrival to South America (Crossby, 2003; Donkin, 1985; Wernicke, 1938).

In 1536, during the first foundation of Buenos Aires by Pedro De Mendoza, the first domestic pigs arrive to the Río de la Plata river (Argentina). In 1541, the settlement was abandoned due to the strong famine produced by lack of food resources, added to the frequent attacks of the indigenous population (Schmidl, 2010). As a result, some of the animals were released, and this first free ranging pigs gave rise to the first feral pig populations, which rapidly occupied the plains and the hills of the current Buenos Aires Province (Cardiel, 1930; Giberti, 1985; Iriart, 1997; Morris, 1956; Sánchez Labrador, 1936; Schmidl, 2010). These first free ranging animals belonged to Hispanic Iberian breeds (negra lampiña, rubia andaluza, gallega, manchado de jabugo and perigordina), Portuguese breeds (alentejana and bísara) and those breeds local to the Canary Islands, Cape Verde and the Portuguese settlings in Rio de Janeiro, all stops in De Mendoza's travel towards the Río de la Plata river (Freitas and Rosado, 2014). 


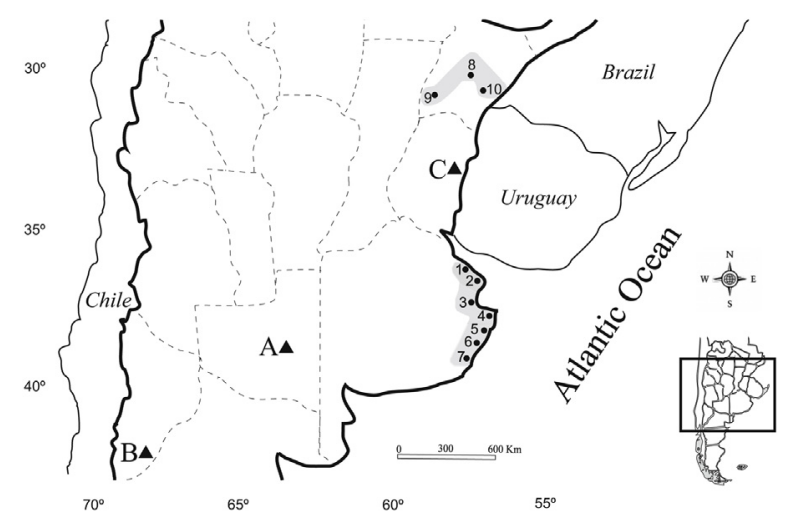

Fig. 1. Sampling sites in populations of feral pigs from Buenos Aires and Corrientes provinces, Argentina. The sampling sites are indicated with numbers; letters indicate the wild boar introduction sites in Argentina. 1. Da. A. Juan Blanco, Magdalena, Buenos Aires; 2. Verónica, Punta Indio, Buenos Aires; 3. Bahía Samborombón, Buenos Aires; 4. Gral. Lavalle, Buenos Aires; 5. Pavón, Gral. Lavalle, Buenos Aires; 6. Reserva Laguna Salada Grande, Gral. Madariaga, Buenos Aires; 7. Reserva Provincial Mar Chiquita, Mar Chiquita, Buenos Aires; 8. Rincón del Socorro, Mercedes, Corrientes; 9. Maruchas, Goya, Corrientes; 10. Loma Alta, La Cruz, Corrientes. A. Gral. Acha, Conhelo, La Pampa; B. Lago Espejo, Los Lagos, Neuquén; C. Parque Nacional El Palmar, Colón, Entre Ríos.

During the next centuries, feral pigs' populations expanded through the Argentinian territory, especially in the Atlantic coast, the Paraná and Uruguay rivers margins, the Negro and Colorado rivers outfalls and the plateaus in the territory of the Río Negro Province (Cardiel, 1930; Hudson, 1956; Maeder, 1981; Musters, 1997; Villarino, 1783).

Otherwise, in the beginning of the XX century, the European wild boar (Sus scrofa scrofa) was introduced in La Pampa Province (Argentina) to fulfil a hunting purpose. From this site and other subsequent ones in the Provinces of Neuquén and Entre Ríos (Fig. 1), the wild boar presented a major geographic expansion, both natural and driven by human activity. This situation promoted mating between wild boars and feral pigs, giving origin to a complex interrelation among the species' different morphotypes (Navas, 1987; Novillo and Ojeda, 2008; Sagua et al., 2018).

Currently, feral pig populations inhabit a broad region of the country; the largest and oldest populations being found in the Bahía Samborombón region located in the east of the Buenos Aires Province and Corrientes Province (Fig. 1). These feral populations have gone through more than 400 years of environmental adaptation and constitute a genetic reservoir, with a direct bond to the breeds originally introduced by the Spanish conquerors.

The feral pig population from Bahía Samborombón, of an estimated size of 10,000 individuals, was established in the early onset of the Spanish conquest. Therefore, the individuals of this population are direct descendants of those originally introduced $150 \mathrm{~km}$ away from Bahía Samborombón, in the site of the first foundation of Buenos Aires (Merino and Carpinetti, 2003; Pérez Carusi et al., 2009). Feral pigs have been proved to present good maternal ability and resistance to diseases of great sanitary relevance, such as trichinosis, classic swine pest and aphthous fever, among others. Consequently, the settlers in the population's surrounding areas, usually use feral pigs as a source of genetic improvement for their domestic pig productions (Carpinetti et al., 2016; Serena et al., 2015).

On the other hand, the feral pig populations from Corrientes were developed from individuals introduced in the XVI century, which rapidly became wild, forming an important food source, both for the natives and the growing colonial population (Maeder, 1981).

Before our research the only records in South America, as to genetic diversity in feral pig populations, are from the studies of
Aravena et al. (2015) and Grossi et al. (2006), for populations from Tierra del Fuego (Chile) and Pantanal (Brazil), respectively.

Nowadays, the advance of molecular techniques coupled with phylogenetic analysis for Sus scrofa, using the control region (CR) of mitochondrial DNA and the Y chromosome marker, are key to unravel the history of the introduction of wild populations, variability levels and population structure (Aravena et al., 2015; Gongora et al., 2004; Iacolina et al., 2016; Kim et al., 2002; Larson et al., 2010; Ramírez et al., 2009; Scandura et al., 2008; Veličković et al., 2015). Particularly the use of CR sequences, have allowed the identification of the geographic distribution for the different clades: E1 (widely distributed in the European continent), subdivided in E1-A (Italy, France, Germany, and Austria), and E1-C (Iberian Peninsula and Central Europe), E2 (restricted to Italian Peninsula, Sardinia and Croatia), NE (Near Eastern) and A (Asian) (Alexandri et al., 2012; Fang and Andersson, 2006; Giuffra et al., 2000; Kusza et al., 2014; Ramírez et al., 2009). On the other hand, studies based on the amelogenin gene present in the Y chromosome (AmelY), have allowed the identification of three present haplogroups: HY1, HY2 and HY3. In the HY1, we frequently found domestic pigs and wild boars of European and Asian ascendancy; in HY2, European wild boars and domestic pigs, as well as African wild boars; at last, in HY3, African pig breeds are predominant (Ramírez et al., 2009).

The aim of this work is to obtain the first description of the genetic variation for the oldest populations of feral pigs in Argentina, through the mitochondrial CR and AmelY markers. These results are analysed and discussed, in order to clarify the phylogenetic origin of these populations, and corroborate their consistency with the historical records.

\section{Material and methods}

\section{Study area and sampling}

A total of $\mathrm{N}=136$ samples of epithelial and muscular tissues were collected from feral pigs from Buenos Aires $(\mathrm{N}=102)$ and Corrientes $(\mathrm{N}=34)$ Provinces, Argentina (Fig. 1; Table 1). Samples were obtained from the different localities through collaborators. They were stored in $96 \%$ ethyl alcohol at $-20^{\circ} \mathrm{C}$ in the sample bank of the Centro de Bioinvestigaciones (Pergamino, Argentina) until processing.

Buenos Aires' populations are located in the Pampa ecoregion (Matteucci, 2012), characterized by a prairie ecosystem and a temperate sub-humid climate, with medium annual temperatures between 14 and $16^{\circ} \mathrm{C}$ and a rainfall of $700-1200 \mathrm{~mm} /$ year (Iriondo, 1995). The predominant vegetation is grass steppe or pseudosteppe, with floodable plains comprised by brackish substrate and halophilic vegetation.

Populations from Corrientes are distributed over two different ecoregions. The locality of Loma Alta, is located in the Mesopotamian savannah ecoregion, have a landscape composed of natural humid grassland sites on flat lowlands, locally known as "malezales" (Carnevali, 1994; Di Giácomo and Casenave, 2010). The preponderance of one or a few tall grass species is characteristic to this ecoregion (Etchepare et al., 2013). The climate is humid subtropical without a delimited dry season; medium temperatures are of $19-20^{\circ} \mathrm{C}$ and rainfalls of $1200 \mathrm{~mm}$ per year. Otherwise, the locality of Rincón del Socorro and Maruchas, are located in the Iberá marshes ecoregion, which comprises a set of functionally related ecosystems, among which, the marsh habitats are predominant (Neiff, 2004). The landscape is dominated by lagoons, dams of floating vegetation and marshes. The medium temperatures in this humid subtropical climate are between 16 and $28^{\circ} \mathrm{C}$, with rainfalls of $1800 \mathrm{~mm}$ per year. Given the different habitats found in this ecoregion, vegetation associations are found, with Cyperus gigan- 
Table 1

Sampling sites, indicating sample ID, Origin (locality), geographic coordinates, number of samples (N), Status (feral pig or wild boar) and Reference.

\begin{tabular}{|c|c|c|c|c|c|c|}
\hline ID site & Locality & Province & Geographical Coordinates & $\mathrm{N}$ & Status & Reference \\
\hline 1 & Da. A. Juan Blanco, Magdalena & Buenos Aires & $35^{\circ} 4^{\prime} 54.86^{\prime \prime} \mathrm{S} 57^{\circ} 18^{\prime} 17.366^{\prime \prime} \mathrm{W}$ & 1 & Feral pig & This study \\
\hline 2 & Verónica, Punta Indio & Buenos Aires & $35^{\circ} 21^{\prime} 54.495^{\prime \prime} \mathrm{S} 58^{\circ} 17^{\prime} 14.283^{\prime \prime} \mathrm{W}$ & 1 & Feral pig & This study \\
\hline 3 & Bahía Samborombón & Buenos Aires & $36^{\circ} 17^{\prime} 35^{\prime \prime} \mathrm{S} 57^{\circ} 19^{\prime} 03^{\prime \prime} \mathrm{W}$ & 81 & Feral pig & This study \\
\hline 4 & Gral. Lavalle & Buenos Aires & $36^{\circ} 21^{\prime} 18.439^{\prime \prime} \mathrm{S} 56^{\circ} 23^{\prime} 23.703^{\prime \prime} \mathrm{W}$ & 5 & Feral pig & This study \\
\hline 5 & Pavón, Gral. Lavalle & Buenos Aires & $36^{\circ} 42^{\prime} 50.04^{\prime \prime} \mathrm{S} 56^{\circ} 44^{\prime} 20.04^{\prime \prime} \mathrm{W}$ & 3 & Feral pig & This study \\
\hline 6 & Reserva Laguna Salada Grande,Gral. Madariaga & Buenos Aires & $36^{\circ} 57^{\prime} 34.3^{\prime \prime} \mathrm{S} 56^{\circ} 57^{\prime} 43.6^{\prime \prime} \mathrm{W}$ & 3 & Feral pig & This study \\
\hline 7 & Reserva Provincial Mar Chiquita, Mar Chiquita & Buenos Aires & $37^{\circ} 40^{\prime} 40.001^{\prime \prime} \mathrm{S} 57^{\circ} 30^{\prime} 0^{\prime \prime} \mathrm{W}$ & 8 & Feral pig & This study \\
\hline 8 & Rincón del Socorro, Mercedes & Corrientes & $28^{\circ} 38^{\prime} 46.94^{\prime \prime} \mathrm{S} 57^{\circ} 25^{\prime} 52.59^{\prime \prime} \mathrm{W}$ & 25 & Feral pig & This study \\
\hline 9 & Maruchas, Goya & Corrientes & $29^{\circ} 10^{\prime} 0.12^{\prime \prime} \mathrm{S} 59^{\circ} 4^{\prime} 0.48^{\prime \prime} \mathrm{W}$ & 3 & Feral pig & This study \\
\hline 10 & Loma Alta, La Cruz & Corrientes & $29^{\circ} 3^{\prime} 0^{\prime \prime} \mathrm{S} 57^{\circ} 4^{\prime} 59.88^{\prime \prime} \mathrm{W}$ & 6 & Feral pig & This study \\
\hline A & Gral. Acha, Conhelo & La Pampa & $37^{\circ} 22^{\prime} 41.472^{\prime \prime} \mathrm{S} 64^{\circ} 36^{\prime} 15.494 \mathrm{~W}$ & - & Wild boar & Sagua et al., 2018 \\
\hline $\mathrm{B}$ & Lago Espejo, Los Lagos & Neuquén & $40^{\circ} 41^{\prime} 25^{\prime \prime} \mathrm{S} 71^{\circ} 41^{\prime} 41^{\prime \prime} \mathrm{W}$ & - & Wild boar & Sagua et al., 2018 \\
\hline $\mathrm{C}$ & Parque Nacional El Palmar, Colón & Entre Ríos & $31^{\circ} 40^{\prime} 17.5^{\prime \prime} \mathrm{S} 58^{\circ} 14^{\prime} 2.7^{\prime \prime} \mathrm{W}$ & - & Wild boar & Sagua et al., 2018 \\
\hline Total & & & & 136 & & \\
\hline
\end{tabular}

teus communities, dams with water hyacinths and other aquatic plants that form floating islets.

Therefore, the characteristics given by these three ecoregions to the feral pigs are fundamental for the survival and reproduction of the species, leading to an exponential growth of the population.

\section{Laboratory analysis and sequencing}

Genomic DNA was extracted following the "phenol-chloroform protocol" (Sambrook and Russell, 2006). DNA from each specimen was eluted in $100 \mu \mathrm{l}$ of Tris-EDTA buffer solution and stored at $-20^{\circ} \mathrm{C}$, under sterile conditions to preclude contamination until sample use for polymerase chain reaction (PCR) analysis.

For the complete set of sequences $(N=136)$, a 734 bp fragment of CR between sites 15,390 and 16,124 was amplified by PCR using RCf 5'-CGCCATCAGCACCCAAAGCT-3' and RCr 5'ACCATTGACTGAATAGCACCT-3' primers (Alves et al., 2003). A subset of $\mathrm{N}=50$ samples was used to identify polymorphic sites in the Y chromosome. For this, a 543 bp fragment of the AmelY gene was amplified by PCR using the primers described by Ramírez et al., 2009 (AmelY-proFW 5'-GCGTTACATGCATATTGCCTTG-3' and AmelY-E1Rv 5'-TCAAGGATGCTGGAGCTTTT-3').

PCR reaction was set to a final volume of $20 \mu \mathrm{L}$, containing: 25-100 ng of template DNA, $1.5 \mathrm{mM} \mathrm{Cl}_{2} \mathrm{Mg}, 0.2 \mu \mathrm{M}$ of each primer, $0.2 \mathrm{mM}$ of each dNTP, $1 \mathrm{X}$ reaction buffer, $0.5 \mathrm{U}$ of Taq T-Plus DNA polymerase and ultrapure sterile water to come to final volume. Thermocycling conditions were set at $94^{\circ} \mathrm{C}$ for $5 \mathrm{~min}$, followed by 30 cycles of $45 \mathrm{~s}$ at $94^{\circ} \mathrm{C}, 62^{\circ} \mathrm{C} \mathrm{CR}$ and $55^{\circ} \mathrm{C}$ AmelY for $45 \mathrm{~s}$, and $45 \mathrm{~s}$ at $74^{\circ} \mathrm{C}$, with a final extension at $74^{\circ} \mathrm{C}$ for $5 \mathrm{~min}$. All amplifications were performed in conjunction with a negative control (distilled water). DNA fragment amplification was confirmed by electrophoresis on $1 \%$ agarose gel, stained with ethidium bromide and visualized under UV light.

Amplification products were purified using $10 \mathrm{U}$ of Exonuclease I and $1 \mathrm{U}$ of FastAp thermosensible alkaline phosphatase, incubating at $37^{\circ} \mathrm{C}$ for $15 \mathrm{~min}$ and then at $85^{\circ} \mathrm{C}$ for another $15 \mathrm{~min}$ to stop the reaction. These purified PCR products were sequenced by Macrogen Co. Ltd. (South Korea).

\section{Data analysis}

The sequences obtained for both molecular markers were visualized and manually edited using BioEdit v.7.0.5 (Hall, 1999), resulting in fragments of $641 \mathrm{bp}$ and $510 \mathrm{bp}$, for CR and AmelY, respectively.

Haplotype and nucleotide diversities and number of polymorphic sites were calculated making use of DnaSP 5.10.1 (Librado and Rozas, 2009). Haplotype sequences were loaded into the GenBank nucleic acid sequence database (http://www.ncbi.nlm.nih. gov/genbank) with accession number MN539114-MN539137 for CR and MN544275-MN544278 for AmelY.

To perform the phylogenetic analysis, as well as to determine the haplotype relationships, $148 \mathrm{CR}$ and 32 AmelY sequences were taken from the GenBank nucleic acid database, which include European and Argentinian wild boars, European and Asian domestic pigs and feral pigs from Chile (Appendix A). In the case of wild boars in Argentina, we employed only four haplotypes from the introduction centres, located in the provinces of La Pampa, Entre Ríos and Neuquén, analysed in the research of Sagua et al., 2018 (Fig. 1; Table 1). Feral pigs from Chile were employed in order to evaluate their relationship with feral populations in Argentina.

A multiple alignment was performed for the complete set of sequences, using ClustalW algorithm in the MEGA v.6 software (Tamura et al., 2013). This alignment was used to obtain the phylogenetic trees, which were built with Bayesian and Neighbour Joining (NJ) methods of statistical inference. For the NJ phylogeny, the nodes' confidence degree was assigned by bootstrapping with 1000 replicates through the software MEGA v.6 (Felsenstein, 1985). In the Bayesian analysis, the mutational model that best fits the data set was determined through JModelTest software v2.1.4 (Darriba et al., 2012; Hasegawa et al., 1985). The data was subsequently converted into BEAST XML format through BEAUti 1.7.5 (Drummond et al., 2012). For the tree reconstruction for both molecular markers, the following settings were used: strict clock as molecular clock rate variation model and 50,000,000 generations Monte Carlo Markov Chain length, sampling every 1000 . All calculations were performed in BEAST (Drummond et al., 2012); the first 25\% of the sampling trees and estimated parameters were discarded as burn-in with TreeAnnotator v1.7.5 (Drummond et al., 2012). FigTree v1.4.0 was employed to visualize the phylogenetic tree (Rambaut, 2012).

The relationships between haplotypes were attained making use of the Median-Joining algorithm through the PopART v1.7 software (Bandelt et al., 1999; Leigh and Bryant, 2015).

In order to evaluate population expansion through the CR marker, the pig population was divided in the Corrientes and Buenos Aires groups, tested for neutrality with Tajima's D and Fu $\mathrm{F}_{\mathrm{S}}$ tests in Arlequin 3.5 (Excoffier and Lischer, 2010).

\section{Results}

\section{Control region}

For the complete set of Sus scrofa sequences $(\mathrm{N}=284)$, of the 93 found haplotypes, 24 contain sequences of feral pigs obtained in this study, 21 of them being new haplotypes and the remaining three (H1, H3 and H4), previously reported for Europe and Caucasus (Table 2; Appendix A). For these 24 haplotypes, 36 variable sites were found, of which, 28 are parsimony-informative sites, 5 
Table 2

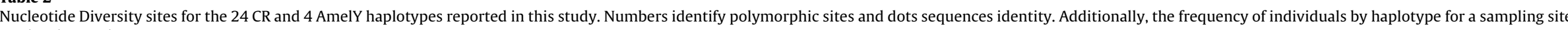
can be observed.

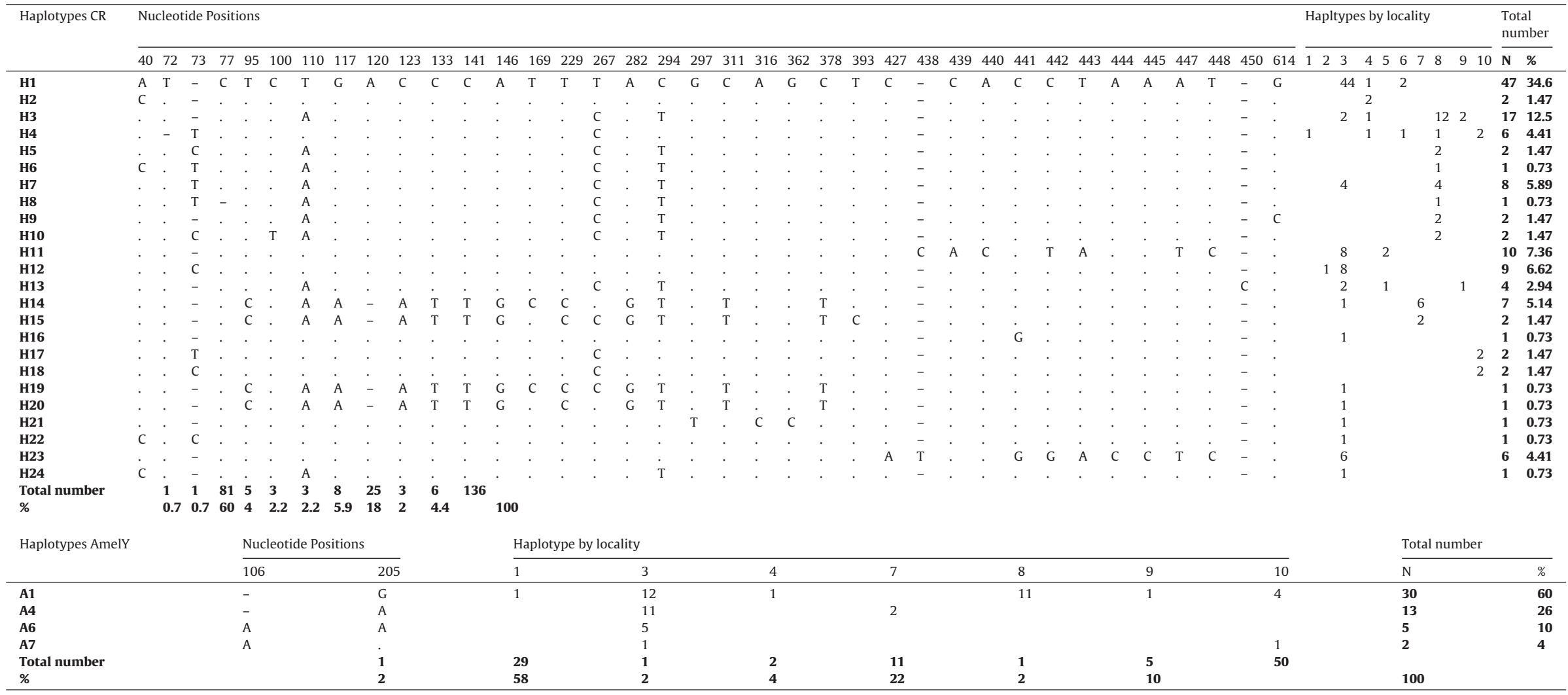


singletons and 3 sites with gaps or missing data (Table 2). The haplotype diversity was $\mathrm{Hd}=0.710 \pm 0.033$ and the nucleotide diversity $\mathrm{Pi}=0.00612 \pm 0.00078$.

Regarding the phylogenetic analysis, both the Bayesian and the NJ trees, showed the same topology (Fig. 2; Appendix B). From the Bayesian inference, it transpires that $\mathrm{HKI}+\mathrm{G}$ is the mutational model that best explains our data (Hasegawa et al., 1985). The different haplotypes, obtained from the Buenos Aires' and Corrientes' populations of feral pigs, can be observed in the phylogenetic tree in the subclades previously reported as E1-A, E1-C and the A clade.

In the E1-A subclade, the found haplotypes are $\mathrm{H} 1, \mathrm{H} 2, \mathrm{H} 4, \mathrm{H} 11$, $\mathrm{H} 12, \mathrm{H} 16-\mathrm{H} 18$ and $\mathrm{H} 21-\mathrm{H} 23$. In the E1-C subclade, the haplotypes are H3, H5-H10, H13 and H24. At last, in clade A, H14, H15, H19 and $\mathrm{H} 20$ are found.

For the Buenos Aires feral pig populations, $78.21 \%$ of the analysed sequences correspond to the subclade E1-A (H1, H2, H4, H11, $\mathrm{H} 12, \mathrm{H} 16, \mathrm{H} 21-\mathrm{H} 23)$, while $13.59 \%$ belong to the E1-C subclade ( $\mathrm{H} 3$, $\mathrm{H} 7, \mathrm{H} 13, \mathrm{H} 24)$ and the remaining $8.2 \%$, to the A clade $(\mathrm{H} 14, \mathrm{H} 15$, H19, H20) (Fig. 3).

As to the feral pig populations from Corrientes, $79.4 \%$ of the analysed sequences are found in the E1-C subclade (H3, H5-H10, H13), while the other $20.6 \%$ belongs to the E1-A subclade (H4, H17, H18) (Fig. 3).

The Median-Joining haplotype network supports the relationships suggested by the phylogenetic analysis, where the link between feral pig and wild boars' haplotypes from Argentina can be visualized, as well as their relative place and relationships into the subclades E1-A, E1-C and A clade (Fig. 4). Moreover, 13 mutational steps separating clades E1 and A can be visualized.

Tajima's D neutrality test for the Buenos Aires and Corrientes groups was not significant ( -0.79 and -0.362 respectively); however, Fu's FS test resulted in values of -0.27 for Buenos Aires and -3.13 for Corrientes, being significant $(\mathrm{p} \leq 0.05)$ for this last population.

\section{AmelY}

For the analysed set of Sus scrofa sequences $(\mathrm{N}=80)$, seven haplotypes were found, four of which contain sequences of feral pigs generated in this study, A6 and A7 correspond to new haplotypes, while A1 and A4 being previously reported (Table 2; Appendix A). Two variable sites are detected among the four haplotypes found in the samples from Argentina, with a value of $\mathrm{Hd}=0.47 \pm 0.0016$ for haplotype diversity and a nucleotide diversity of $\mathrm{Pi}=0.00092 \pm 0.00008$ (Table 2).

Both the Bayesian and the NJ phylogenetic trees present the same topology (Fig. 5, Appendix C). According to the Bayesian inference, our data fits best to the HKI + I mutational model (Hasegawa et al., 1985).

In the Bayesian phylogenetic tree, the four obtained haplotypes can be visualized as part of the groups previously reported as HY1 and HY2 (Fig. 5, Appendix C). Notably, only sequences from the Buenos Aires feral pig populations are found in the HY1 haplogroup (A4, A6); while the haplogroup HY2 contains sequences from both provinces in the same frequency (A1 and A7) (Fig. 5; Appendix A).

\section{Discussion}

In this study, we present the first results regarding genetic variability and phylogenetic origin in feral pig populations from Argentina, particularly from the largest and oldest Buenos Aires and Corrientes populations.

Historical records indicate that part of the domestic pigs that arrived in South America during the XV century, coming from the Iberian Peninsula, Canary Islands and Cape Verde (Burgos-
Paz et al., 2013; Crossby, 2003; Donkin, 1985; Wernicke, 1938), originated the feral populations that expanded throughout the Argentinian territory later on (Cardiel, 1930; Giberti, 1985; Iriart, 1997; Morris, 1956; Sánchez Labrador, 1936). In the XX century, with the wild boar arrival to Argentina, a more complex interrelations pattern arose, presenting interactions among domestic pigs (including hybrid breeds), feral pigs and wild boars (Navas, 1987; Novillo and Ojeda, 2008; Sagua et al., 2018).

The phylogenetic analysis for the CR marker, partially support the historic records, finding feral pigs from Buenos Aires populations of both, European and Asiatic ascendancy (Mar Chiquita population and few individuals from Bahía Samborombón); this suggests the possibility of different colonization events. In this sense, the greatest haplotype diversity in feral pig populations from Buenos Aires, compared to those from Corrientes, is probably due to the European (E1-A and E1-C) and Asian lineage contribution. Furthermore, most individuals from Buenos Aires populations were grouped in the E1-A subclade, while those from Corrientes were mainly found on the E1-C subclade, supporting the hypothesis of more than one colonization event.

The E1-A subclade is mainly comprised with domestic pigs from the Portugal and Canary Islands, while subclade E1-C holds individuals from the Iberian Peninsula (Alves et al., 2003, 2010; Fang and Andersson, 2006; Kim et al., 2002; Kuzsa et al., 2014; Larson et al., 2005; Watanobe et al., 2003). Based on these records, our genetic results are in concordance with the historical information.

Previous studies on genetic diversity making use of the $C R$ marker in feral pig populations in Chile and Brazil, showed European ascendancy on all individuals studied (Aravena et al., 2015; Grossi et al., 2006). On the other hand, there is evidence that feral pig populations from Tierra del Fuego (Chile) are more recent than the Argentinian populations, being established over the XIX century (Aravena et al., 2015; Gade, 1987). In our study, feral pigs from Tierra del Fuego presented haplotypes ( $\mathrm{H} 28$ and $\mathrm{H} 29$ ) related to the ones from Corrientes (H17 and H5), and showing haplotype identity with Iberian breeds as well. The genetic closeness between this geographically distant feral populations, may be ought to the scarce or absent intervention of other morphotypes, entailing to a gene pool nearly identical to that of Iberian breeds (Aravena et al., 2015; Gade, 1987).

There are controversies as to the Pantanal feral pig population (Brazil), which is known to be over 200 years old. Sollero et al. (2009) indicates that the first individuals arrived in 1864, after the Paraguayś war; on the other hand, Gonela (2003) argues that this feral "porcos monteiros" are descendants of the pigs brought by the conquerors in 1778, during Alburquenque's foundation (currently Corumbá). Given that the "porcos monteiros" sequences are not available in GenBank, we were unable to include them in our study.

Regarding the origin of individuals of feral pigs in the clade $A$ is difficult to explain, considering that the original Iberian pig breeds did not present Asian gene introgressions (Alves et al., 2003) and given that, up to date, the only evidence of a direct introduction of Asian pigs to the American continent is the case of the Cuino pig in Mexico (Burgos-Paz et al., 2013; Lemus and Ly, 2010). However, it is known that there was an indirect Asian contribution to European breeds can be traced to the XVIII-XIX centuries, when genic Asian introduction was utilized for breeding purposes. Therefore, those European domestic pigs that arrived to Argentina might have carried an Asian component in their gene pool (Alves et al., 2003; Giuffra et al., 2000; Kim et al., 2002).

Other possible explanation as to the presence of Asian variants in feral populations, could be the mating of local feral pigs with modern domestic breeds. Currently, the most spread breeds in Argentina are Landrace, Large White, Hampshire and Duroc; through CR and Cytochrome $b$ markers, previous studies identified 


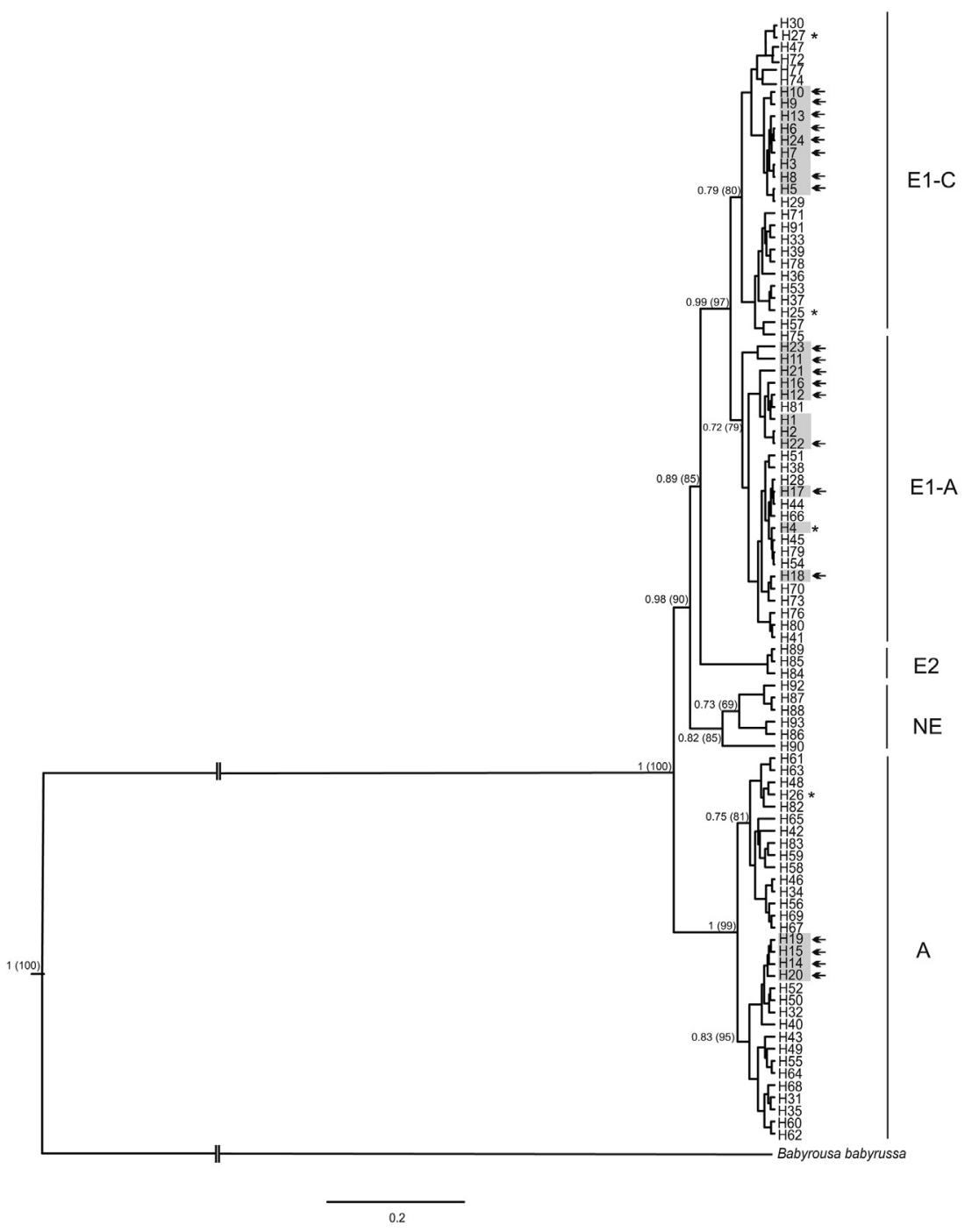

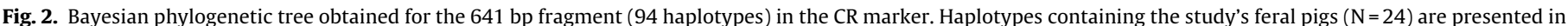

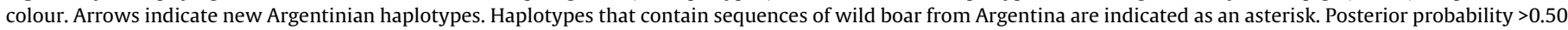
is expressed in the nodes. Parenthesis specify boostrap values $>50 \%$.

them as related to the Asian clade (Alves et al., 2003; Giuffra et al., 2000; Kim et al., 2002).

Another contribution to Buenos Aires feral pig population's major genetic diversity, might be introduction of wild boar coming from the province of La Pampa in 1973 to "El Destino" natural reserve (Magdalena county) at the north of Bahía Samborombón (Giménez-Dixon, 1991).

In other respects, historical records report that some of the individuals to enter the country, were of African provenance (Cape Verde islands). Hence, we employed the AmelY marker to explore African lineage presence in feral pig populations from Argentina. Previous studies with mitochondrial (CR) and nuclear markers (UTY, SRY, NRY y MC1R), report that African pigs have a particularly complex ancestry, given that their origin can be traced back to Europe, Asia's Southeast and India (Adeola et al., 2017; Noce et al., 2015; Osei-Amponsah et al., 2017).

Through this analysis we do not detect any African component in the studied populations of feral pigs, because the found haplotypes in Buenos Aires' populations belong to the HY1 and HY2 haplogroups, while the Corrientes populations were grouped in the HY2 haplogroup, indicating strong European and Asian ascendancy. These results differ from those obtained by Ramírez et al. (2009), who reported an individual with African origins (HY3) in Entre Rios, Argentina. Moreover, this marker allowed the recognition of greater haplotype diversity in Buenos Aires populations, concurrent with the results for the CR marker.

The CR-estimated gene diversity for Argentinian feral populations was lower than that reported for domestic breeds and European wild boars (Alves et al., 2010; Van Asch et al., 2012). Particularly, for Argentina's data set of feral pigs, the haplotype diversity $(\mathrm{Hd}=0.710 \pm 0.033$ ) is lower than reported for Argentina's wild boars ( $\mathrm{Hd}=0.827 \pm 0.017$ ), European domestic breeds ( $\mathrm{Hd}=0,886 \pm 0,008)$, European feral pigs $(\mathrm{Hd}=0.791 \pm 0.089)$ and European wild boars $(\mathrm{Hd}=0,912 \pm 0,007)$, both in the Iberian Peninsula $(\mathrm{Hd}=0.92 \pm 0.01)$ and in Central Europe $(\mathrm{Hd}=0.89 \pm 0.07$ ) (Alves et al., 2010; Sagua et al., 2018; Van Asch et al., 2012). In the same manner, the nucleotide diversity value for the feral pigs from this study $(\mathrm{Pi}=0.00612 \pm 0.00078)$ was lower to the ones reported for wild boars from Argentina $(\mathrm{Pi}=0.007 \pm 0.001)$, European domestic $(\mathrm{Pi}=0,016 \pm 0,008)$ and feral pigs $(\mathrm{Pi}=0,009 \pm 0,005)$, as well as European wild boars ( $\mathrm{Pi}=0,012 \pm 0,006$ ) (Alves et al., 2010; Sagua et al., 2018; Van Asch et al., 2012). The reduced genetic diversity observed for Argentinian feral pig populations, in contrast to ancestral European domestic pig populations, is probably a consequence of the founder effect 


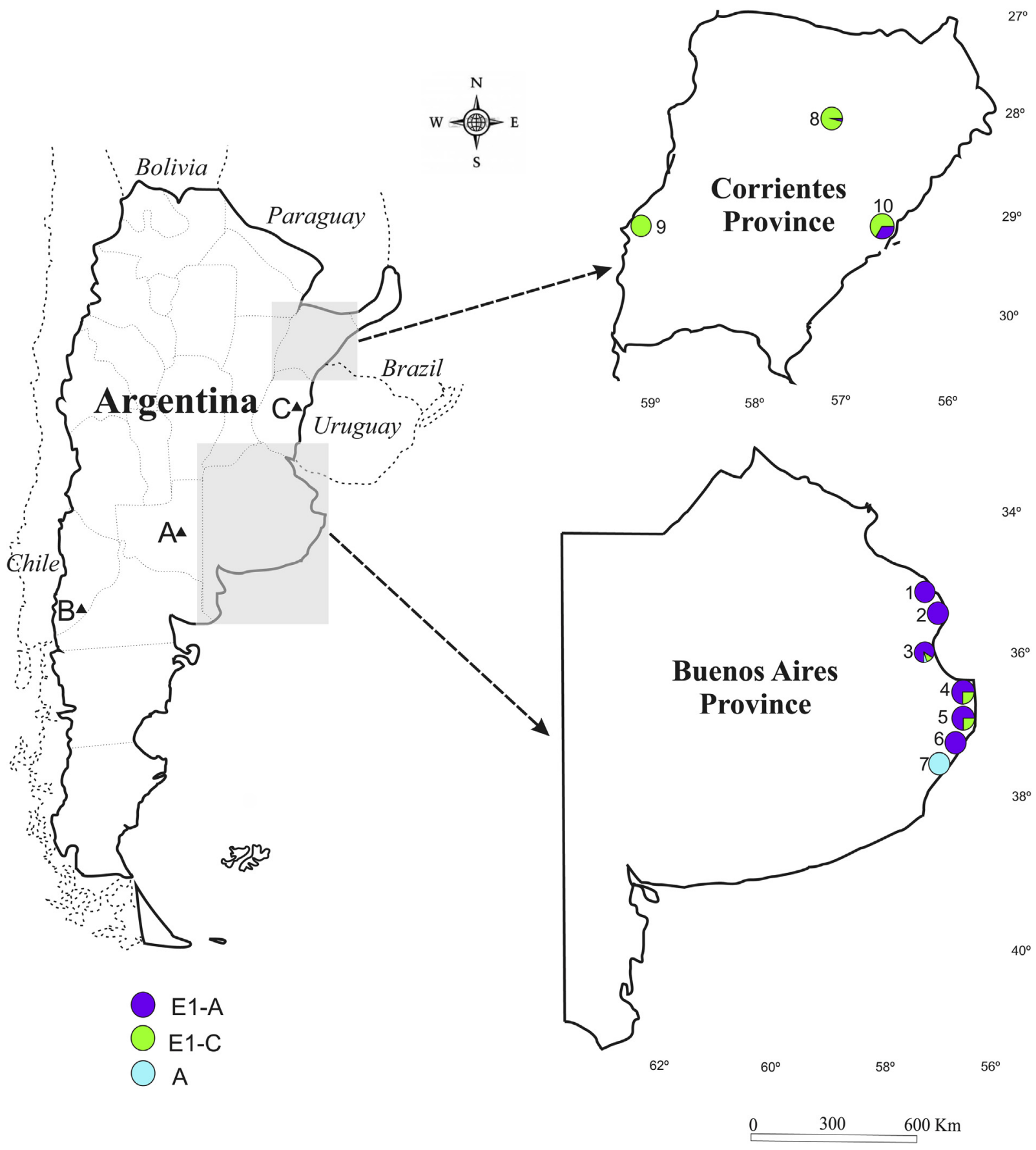

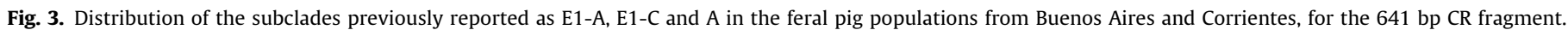
Numbers indicate sampling sites and letters show main wild boar introduction sites. Colours illustrate subclades E1-A, E1-C and A.

from the small amount of individuals that arrived to the country in the XV century and gave origin to these populations.

On the other hand, our results are compatible with a scenario of recent expansion in both population groups studied of feral pigs, but most visibly, in populations from Corrientes. The afore mentioned expansions might be induced by the humid and highly productive habitats, as well as the lack of predators, other than the human-inflicted hunting pressure (Carpinetti, 2015; Merino and Carpinetti, 2003; Neiff and Poi de Neiff, 2006; Volpedo et al., 2005).

In conclusion, this is the first study to analyse phylogenetic origin in Argentina's oldest feral pig populations. Our results are consistent with the available historical records, building up to a preliminary confirmation of the European ascendance for most individuals studied, with exception of those cases where Asian origin was identified. Up to this moment, African lineage presence hasn't been detected.

In order to shed more light as to the population dynamics for feral pigs in Argentina, future studies should contemplate additional sampling sites inside the species' distribution, as well as the use of different molecular markers, such as microsatellites. Furthermore, it is important to point out these populations' economic importance to the national livestock activity, given their use as a genetic resource for low budget domestic productions.

On the other hand, in all areas where naturalized populations of Sus scrofa are found, they are known to generate a large negative impact on flora and fauna. For the flora, it is known that 


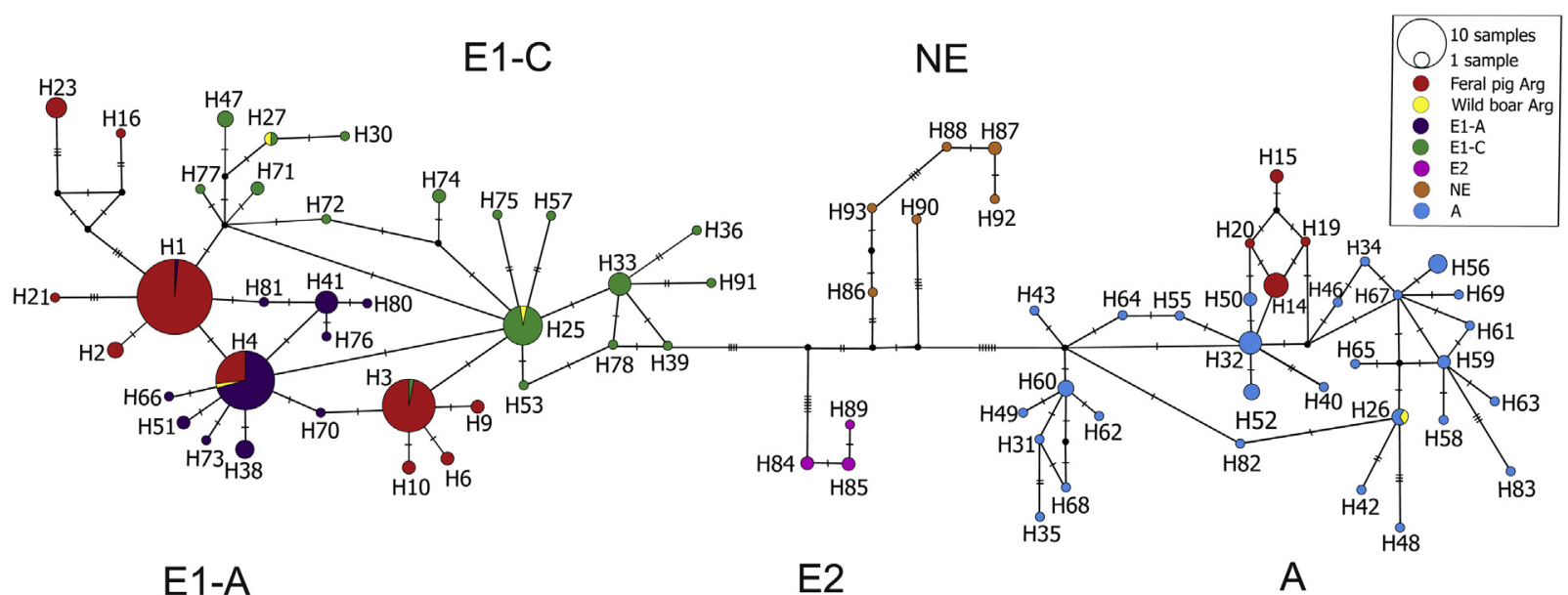

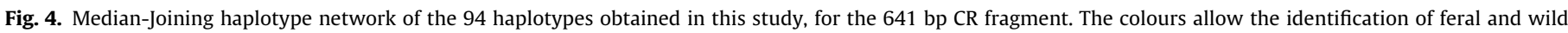

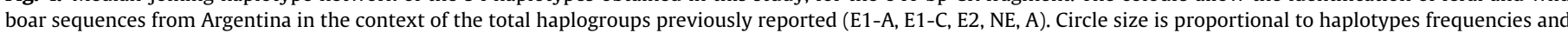
transversal lines between haplotypes represent the number of mutations that separate them.

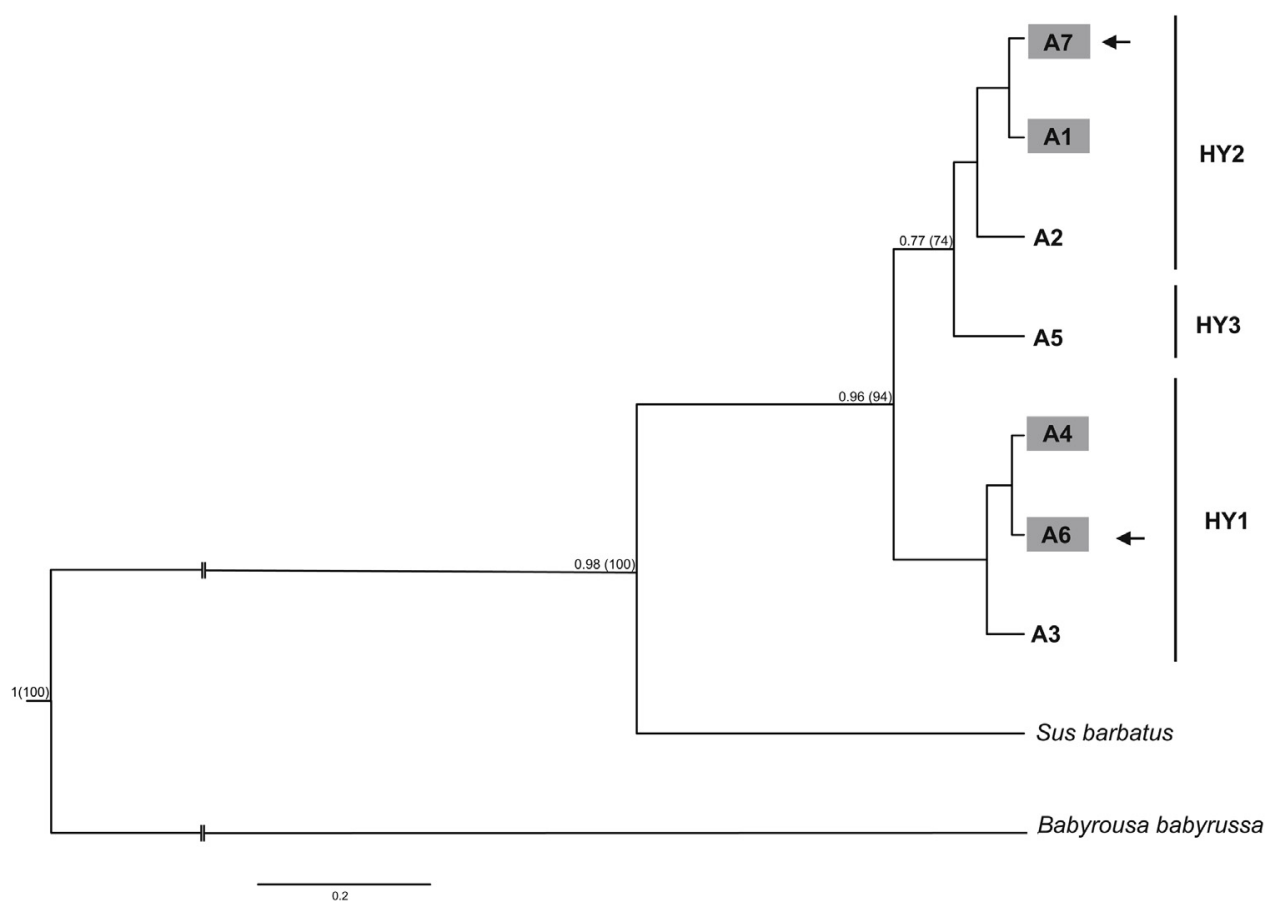

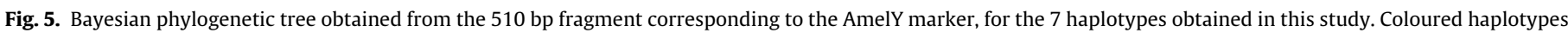

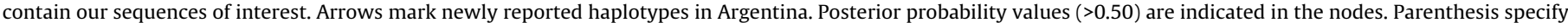
boostrap values $>50 \%$.

modifications of species composition, local plant extinction, diversity reduction and soil cover alteration facilitate the colonization of exotic plants. Additionally, fauna is affected by predation, nest destruction, food competition and habitat destruction (Ballari et al., 2016; Carpinetti et al., 2014).

Currently in Argentina, there is a process of species control in certain protected areas, where the most used and effective technique is hunting, and the following are traps (Ballari et al., 2014). As the species is distributed throughout the entire country, this task in such a restricted area is not sufficient for control, since in the other sites they are in full expansion. Therefore, to increase efficiency, it is essential to develop a strategic project that includes the use of various techniques and seeing it through, with participation of regional, provincial and national institutions, to effectively visualize a reduction of the species (Ballari et al., 2014, 2016).
Consequently, knowledge on this species is a fundamental starting point for the design of preservation strategies for natural ecosystems and the genetic resources that these populations represent.

\section{Acknowledgements}

We thank Soledad Barandiaran, Agustin Abba, Alberto Cabrera, Gabriel Castresana and Pablo Rojas for their help in collecting feral pig samples, as well as Lucila Pérez Gianmarco, for her help with the English revision. Universidad Nacional del Noroeste de la Provincia de Buenos Aires (UNNOBA), Comisión de Investigaciones Científicas de la Provincia de Buenos Aires (CICPBA), and Consejo Nacional de Investigaciones Científicas y Técnicas (CONICET) provided financial support for the present research. 


\section{Appendix A. Supplementary data}

Supplementary material related to this article can be found, in the online version, at doi:https://doi.org/10.1016/j.mambio.2019. 09.013.

\section{References}

Adeola, A.C., Oluwole, O.O., Oladele, B.M., Olorungbounmi, T.O., Boladuro, B., Olaogun, S.C., Frantz, L., 2017. Analysis of the genetic variation in mitochondrial DNA, Y-chromosome sequences, and MC1R sheds light on the ancestry of Nigerian indigenous pigs. Genet. Sel. Evol. 49 (1), 52-57, http://dx. doi.org/10.1186/s12711-017-0326-1.

Alexandri, P., Triantafyllidis, A., Papakostas, S., Chatzinikos, E., Platis, P., Papageorgiou, N., Larson, G., Abatzopoulos, T.J., Triantaphyllidis, C., 2012. The Balkans and the colonization of Europe: the post-glacial range expansion of the wild boar, Sus scrofa. J. Biogeogr. 39 (4), 713-723, http://dx.doi.org/10.1111/j. 1365-2699.2011.02636.x.

Alves, E., Ovilo, C., Rodriguez, M.C., Silio, L., 2003. Mitochondrial DNA sequence variation and phylogenetic relationships among Iberian pigs and other domestic and wild pig populations. Anim. Genet. 34 (5), 319-324, http://dx. doi.org/10.1046/j.1365-2052.2003.01010.x.

Alves, C., Pinheiro, I., Godinho, R., Vicente, J., Gortázar, C., Scandura, M., 2010. Genetic diversity of wild boar populations and domestic pig breeds (Sus scrofa) in South-western Europe. Biol. J. Linn. Soc. 101 (4), 797-822, http://dx.doi.org/ 10.1111/j.1095-8312.2010.01530.x.

Aravena, P., Skewes, O., Gouin, N., 2015. Mitochondrial DNA diversity of feral pigs from Karukinka Natural Park, Tierra del Fuego Island, Chile. Genet. Mol. Res. 14 (2), 4245-4257, http://dx.doi.org/10.4238/2015.April.28.6.

Ballari, S.A., Cuevas, M.F., Cirignoli, S., Valenzuela, A.E., 2014. Invasive wild boar in Argentina: using protected areas as a research platform to determine distribution, impacts and management. Biol. Invasions 17 (6), 1595-1602, http://dx.doi.org/10.1007/s10530-014-0818-7.

Ballari, S.A., Kuebbing, S.E., Nuñez, M.A., 2016. Potential problems of removing one invasive species at a time: a meta-analysis of the interactions between invasive vertebrates and unexpected effects of removal programs. PeerJ. 4 e2029, http://dx.doi.org/10.7717/peerj.2029.

Bandelt, H.J., Forster, P., Röhl, A., 1999. Median-joining networks for inferring intraspecific phylogenies. Mol. Biol. Evol. 16 (1), 37-48, http://dx.doi.org/10. 1093/oxfordjournals.molbev.a026036.

Burgos-Paz, W., Souza, C.A., Megens, H.J., Ramayo-Caldas, Y., Melo, M., Lemús-Flores, C., Aguirre, L., 2013. Porcine colonization of the Americas: a 60k SNP story. Heredity. 110 (4), 321-330, http://dx.doi.org/10.1038/hdy.2012.109.

Cardiel, J., 1930. Diario del Viaje y Misión al Río del Sauce por fines de Marzo de 1748. In: Furlong Cardiff, P.G., Outes, F.F. (Eds.), Publicaciones del Instituto de Investigaciones Geográficas de la Facultad de Filosofía y Letras. , coni ed, Buenos Aires, Argentina.

Carnevali, R., 1994. Fitogeografía de la provincia de Corrientes: cartas, escalas 1: 500.000 y 1: 1.000. 000. Gobierno de la Provincia de Corrientes. Instituto Nacional de Tecnología Agropecuaria, Corrientes, Argentina.

Carpinetti, B., Castresana, G., Rojas, P., Grant, J., Marcos, A., Monterubbianesi, M., Borrás, P., 2014. Vigilancia epidemiológica en poblaciones de cerdos silvestres (Sus scrofa). Implicancias para la salud pública, la producción animal y la conservación de la biodiversidad. SNS 6, 67-76.

Carpinetti, B.N., 2015. La Política del "perro del Hortelano". Caza furtiva y especies exóticas en Bahía Samborombón. AVÁ 24, 129-139.

Carpinetti, B.N., Di Guirolamo, G., Delgado, J.V., Martínez, R.D., 2016. El Cerdo Criollo Costero: Valioso recurso zoogenético local de la provincia de Buenos Aires Argentina. Arch. Zootec. 65 (251), 403-407, http://dx.doi.org/10.21071/ az.v65i251.703.

Crossby, A.W., 2003. The Columbian Exchange: Biological and Cultural Consequences of $1492,1^{0}$ ed. Greenwood Publishing Group, http://dx.doi.org/ $10.2307 / 2936788$.

Darriba, D., Taboada, G.L., Doallo, R., Posada, D., 2012. jModelTest 2: more models, new heuristics and parallel computing. Nat. Methods $9(8), 772-776$, http://dx doi.org/10.1038/nmeth.2109.

Di Giácomo, A.S.D., Casenave, J.L.D., 2010. Use and importance of crop and field-margin habitats for birds in a neotropical agricultural ecosystem. Condor 112 (2), 283-293, http://dx.doi.org/10.1525/cond.2010.090039.

Donkin, R.A., 1985. The peccary with observations on the introduction of pigs to the New World. T. Am. Philos. Soc. 75 (5), 1-152, http://dx.doi.org/10.2307/ 1006340.

Drummond, A.J., Suchard, M.A., Xie, D., Rambaut, A., 2012. Bayesian phylogenetics with BEAUti and the BEAST 1.7. Mol. Biol. Evol. 29 (8), 1969-1973, http://dx. doi.org/10.1093/molbev/mss075.

Etchepare, E.G., Ingaramo, M.R., Porcel, E., Álvarez, B.B., 2013. Diversidad de las comunidades de escamados en la Reserva Natural del Iberá, Corrientes, Argentina. Rev. Mex. Biodivers. 84, 1273-1283, http://dx.doi.org/10.7550/rmb. 36248 .

Excoffier, L., Lischer, H.E.L., 2010. Arlequin suite ver 3.5: A new series of programs to perform population genetics analyses under Linux and Windows. Mol. Ecol. Resour. 10, 564-567, http://dx.doi.org/10.1111/j.1755-0998.2010.02847.x.

Fang, M., Andersson, L., 2006. Mitochondrial diversity in European and Chinese pigs is consistent with population expansions that occurred prior to domestication. Proc. R. Soc. Lond. [Biol]. 273 (1595), 1803-1810, http://dx.doi. org/10.1098/rspd.2006.3514.

Felsenstein, J., 1985. Confidence limits on phylogenies: an approach using the bootstrap. Evolution 39 (4), 783-791, http://dx.doi.org/10.1111/j.1558-5646. 1985.tb00420.x

Freitas, A.B., Rosado, M.M., 2014. A introdução dos suínos no Brasil. In: Filha, Olimpia Lima Silva (Ed.), Las Razas Porcinas Iberoamericanas. Un Enfoque Etnozootécnico. Instituto Federal Baiano, Campus Valença, Salvador, Brazil, pp. 39-54.

Gade, D., 1987. The Iberian pig in the central Andes. J. Cult. Geogr. 7 (2), 35-49, http://dx.doi.org/10.1080/08873638709478506.

Giberti, H.C., 1985. Historia económica de la ganadería argentina. Hyspamérica, Buenos Aires, Argentina.

Giuffra, E.J.M.H., Kijas, J.M.H., Amarger, V., Carlborg, Ö., Jeon, J.T., Andersson, L., 2000. The origin of the domestic pig: independent domestication and subsequent introgression. Genetics 154 (4), 1785-1791.

Giménez-Dixon, M., 1991. Estimación de parámetros poblacionales del venado de las Pampas (Ozotoceros bezoarticus celer, Cabrera 1943 -Cervidae-) en la costa de la Bahía Samborombón (Provincia de Buenos Aires) a partir de datos obtenidos mediante censos aéreos. Tesis de Doctorado, Universidad Nacional de La Plata, Argentina.

Gonela, A., 2003. Aplicação de marcadores microssatélites de Sus scrofa domestica na caracterização genética de populações de Sus scrofa sp (porco-Monteiro) e Tayassu pecari (queixada). Tese de doutorado, Universidade de São Paulo, Brasil.

Gongora, J., Fleming, P., Spencer, P.B., Mason, R., Garkavenko, O., Meyer, J.N., Moran, C., 2004. Phylogenetic relationships of Australian and New Zealand feral pigs assessed by mitochondrial control region sequence and nuclear GPIP genotype. Mol. Phylogenet. Evol. 33 (2), 339-348, http://dx.doi.org/10.1016/j. ympev.2004.06.004

Grossi, S.F., Lui, J.F., Garcia, J.E., Meirelles, F.V., 2006. Genetic diversity in wild (Sus scrofa scrofa) and domestic (Sus scrofa domestica) pigs and their hybrids based on polymorphism of a fragment of the D-loop region in the mitochondrial DNA. Genet. Mol. Res. 5 (4), 564-568.

Hall, T.A., 1999. BioEdit: a user-friendly biological sequence alignment editor and analysis program for Windows 95/98/NT. Nucl. Acid 41 (41), 95-98.

Hasegawa, M., Kishino, H., Yano, T.A., 1985. Dating of the human-ape splitting by a molecular clock of mitochondrial DNA. J. Mol. Evol. 22 (2), 160-174, http://dx. doi.org/10.1007/BF02101694.

Hudson, W.H., 1956. Días de ocio en la Patagonia. Continente, Buenos Aires, Argentina.

Iacolina, L., Brajković, V., Canu, A., Šprem, N., Cubric-Curik, V., Fontanesi, L., Saarma, U., Scandura, M., 2016. Novel Y-chromosome short tandem repeats in Sus scrofa and their variation in European wild boar and domestic pig populations. Anim. Genet. 47 (6), 682-690, http://dx.doi.org/10.1111/age.12483.

Iriart, R., 1997. Evolución Histórica de la Pampa Deprimida. In: Berbeglia, C.E. (Ed.), Propuesta para una antropología Argentina IV. Biblos, Buenos Aires, Argentina, pp. 351-368.

Iriondo, M., 1995. La Pampa. In: Argollo, J.P. (Ed.), Climas cuaternarios en América del Sur. Institut Français de Recherche Scientifique pour le Développement en Coopération (Mourguiart ed), La Paz, Bolivia, pp. 283-306.

Kim, K.I., Lee, J.H., Li, K., Zhang, Y.P., Lee, S.S., Gongora, J., Moran, C., 2002. Phylogenetic relationships of Asian and European pig breeds determined by mitochondrial DNA D-loop sequence polymorphism. Anim. Genet. 33 (1) 19-25, http://dx.doi.org/10.1046/j.1365-2052.2002.00784.x.

Kusza, S., Podgorski, T., Scandura, M., Borowik, T., Jávor, A., Sidorovich, V. Jędrzejewska, B., 2014. Contemporary genetic structure, phylogeography and past demographic processes of wild boar Sus scrofa population in Central and Eastern Europe. PLoS One 9 (3), 1-11, http://dx.doi.org/10.1371/journal.pone. 0091401.

Larson, G., Dobney, K., Albarella, U., Fang, M., Matisoo-Smith, E., Robins, J., Rowley-Conwy, P., 2005. Worldwide phylogeography of wild boar reveals multiple centers of pig domestication. Science 307 (5715), 1618-1621, http:// dx.doi.org/10.1126/science.1106927.

Larson, G., Liu, R., Zhao, X., Yuan, J., Fuller, D., Barton, L., Luo, Y., 2010. Patterns of East Asian pig domestication, migration, and turnover revealed by modern and ancient DNA. Proc. Natl. Acad. Sci. U. S. A. 107 (17), 7686-7691, http://dx.doi. org/10.1073/pnas.0912264107.

Leigh, J.W., Bryant, D., 2015. Popart: full-feature software for haplotype network construction. Methods Ecol. Evol. 6 (9), 1110-1116, http://dx.doi.org/10.1111/ 2041-210X.12410.

Lemus, C., Ly, J., 2010. Estudios de sostenibilidad de cerdos mexicanos pelones y cuinos. La iniciativa nayarita. Revista Computadorizada de Producción Porcina 17, 89-98.

Librado, P., Rozas, J., 2009. DnaSP v5: a software for comprehensive analysis of DNA polymorphism data. Bioinformatics 25 (11), 1451-1452, http://dx.doi org/10.1093/bioinformatics/btp187.

Maeder, E.J.A., 1981. Historia económica de Corrientes en el período virreinal 1776-1810. Academia Nacional de la Historia, Buenos Aires, Argentina.

Matteucci, S., 2012. Ecorregión Pampa. In: Morello, S.D., Matteucci, A., Rodriguez, M., Silva, J. (Eds.), Ecorregiones y Complejos Ecosistémicos Argentinos. , pp. 441-500, Buenos Aires, Argentina.

Merino, M.L., Carpinetti, B.N., 2003. Feral pig Sus scrofa populations estimates in Bahía Samborombón Conservation Area, Buenos Aires province, Argentina. Mastozool. Neotrop. 10, 269-275.

Morris, I., 1956. Una narración fiel de los peligros y desventuras que sobrellevó Isaac Morris, $1^{\underline{0}}$ ed, Buenos Aires, Argentina. 
Musters, G.C., 1997. Vida entre los patagones. El Elefante Blanco.

Navas, J.R., 1987. Los vertebrados exóticos introducidos en Argentina. Revista del Museo Argentino de Ciencias Naturales Bernardino Rivadavia. 14 (2), 7-38.

Neiff, J.J., 2004. El Iberá. . . ¿en peligro? Fundación Vida Silvestre Argentina, Buenos Aires, Argentina.

Neiff, J.J., Poi de Neiff, A.S.G., 2006. Situación ambiental de la ecoregión Iberá. In: Brown, A.D., Martínez Ortíz, U., Acerbi, M., Corcuera, J. (Eds.), La situación ambiental argentina, Fundación Vida Silvestre Argentina. , pp. 176-194, Buenos Aires, Argentina.

Noce, A., Amills, M., Manunza, A., Muwanika, V., Muhangi, D., Aliro, T., Mercadé, A., 2015. East African pigs have a complex Indian, Far Eastern and Western ancestry. Anim. Genet. 46 (4), 433-436, http://dx.doi.org/10.1111/age.12305.

Novillo, A., Ojeda, R.A., 2008. The exotic mammals of Argentina. Biol. Invasions 10 (8), 1333-1345, http://dx.doi.org/10.1007/s10530-007-9208-8.

Osei-Amponsah, R., Skinner, B.M., Adjei, D.O., Bauer, J., Larson, G., Affara, N.A. Sargent, C.A., 2017. Origin and phylogenetic status of the local Ashanti Dwarf pig (ADP) of Ghana based on genetic analysis. BMC Genomics 18 (1), 193-205, http://dx.doi.org/10.1186/s12864-017-3536-6.

Pérez Carusi, L.C., Beade, M.S., Miñarro, F., Vila, A.R., Giménez-Dixon, M., Bilenca, D.N., 2009. Relaciones espaciales y numéricas entre venados de las pampas (Ozotoceros bezoarticus celer) y chanchos cimarrones (Sus scrofa) en el Refugio de Vida Silvestre Bahía Samborombón, Argentina. Ecol. Austral 19 (1), 63-71.

Rambaut, A., Available: 2012. FigTree v.1.4.0. http://tree.bio.ed.ac.uk/software/ figtree/.

Ramírez, O., Ojeda, A., Tomas, A., Gallardo, D., Huang, L.S., Folch, J.M. Galman-Omitogun, O., 2009. Integrating Y-chromosome, mitochondrial, and autosomal data to analyze the origin of pig breeds. Mol. Biol. Evol. 26 (9), 2061-2072, http://dx.doi.org/10.1093/molbev/msp118.

Río Moreno, J.L., 1996. El cerdo. Historia de un elemento esencial de la cultura castellana en la conquista y colonización de América (siglo XVI). Anu. Estud. Am. 53 (1), 13-35, http://dx.doi.org/10.3989/aeamer.1996.v53.i1.430.

Sagua, M.I., Figueroa, C.E., Acosta, D.B., Fernández, G.P., Carpinetti, B.N., Birochio, D., Merino, M.L., 2018. Inferring the origin and genetic diversity of the introduced wild boar (Sus scrofa) populations in Argentina: an approach from mitochondrial markers. Mammal Res. 163 (4), 467-476, http://dx.doi.org/10. 1007/s13364-018-0380-2.

Sambrook, J., Russell, D.W., 2006. Rapid isolation of yeast DNA. Cold Spring Harb. Protoc. 2006 (1), 631-632, http://dx.doi.org/10.1101/pdb.prot093542.

Sánchez Labrador, J., 1936. Los indios pampas, puelches, patagones. Viau y Zona, Buenos Aires, Argentina.

Scandura, M., Iacolina, L., Crestanello, B., Pecchioli, E., Di Benedetto, M.F., Russo, V., Davoli, R., Apollonio, M., Bertorelle, G., 2008. Ancient vs. recent processes as factors shaping the genetic variation of the European wild boar: are the effects of the last glaciation still detectable? Mol. Ecol. 17 (7), 1745-1762, http://dx. doi.org/10.1111/j.1365-294X.2008.03703.x.

Schmidl, U., 2010. Viaje al Río de la Plata. Emecé, Buenos Aires, Argentina.

Serena, M.S., Artuso, M.C., Pérez, A., Echeverría, M.G., Laksman, Y., Arocena, G., Carpinetti, B.N., 2015. Vigilancia epidemiológica de las principales virosis que afectan a las poblaciones de cerdos silvestres (Sus scrofa) en distintas zonas de la República Argentina. In: XI Congreso Argentino de Virología, CABA, Argentina, pp. 114-115.

Sollero, B.P., Paiva, S.R., Faria, D.A., Guimarães, S.E.F., Castro, S.T.R., Egito, A.A., Mariante, A.D.S., 2009. Genetic diversity of Brazilian pig breeds evidenced by microsatellite markers. Livest. Sci. 123 (1), 8-15, http://dx.doi.org/10.1016/j. livsci.2008.09.025.

Tamura, K., Stecher, G., Peterson, D., Filipski, A., Kumar, S., 2013. MEGA6: molecular evolutionary genetics analysis version 6.0. Mol. Biol. Evol. 30 (12), 2725-2729, http://dx.doi.org/10.1093/molbev/mst197.

Van Asch, B., Pereira, F., Santos, L.S., Carneiro, J., Santos, N., Amorim, A., 2012. Mitochondrial lineages reveal intense gene flow between Iberian wild boars and South Iberian pig breeds. Anim. Genet. 43 (1), 35-41, http://dx.doi.org/10. 1111/j.1365-2052.2011.02222.x.

Veličković, N., Djan, M., Ferreira, E., Stergar, M., Obreht, D., Maletić, V., Fonseca, C., 2015. From north to south and back: the role of the Balkans and other southern peninsulas in the recolonization of Europe by wild boar. J. Biogeogr. 42 (4), 716-728, http://dx.doi.org/10.1111/jbi.12458.

Villarino, B., 1783. Diario del piloto de la Real Armada Don Basilio Villarino de reconocimiento que hizo del río Negro en la costa oriental de Patagonia el año de 1782. Imprenta del Estado. Colección de Obras y Documentos relativos a la Historia Antigua y Moderna de las Provincias del Río de la Plata, Buenos Aires, Argentina, pp. 967-1138.

Volpedo, A., Yunes Núñez, T., Fernández Cirelli, A., 2005. El Humedal Mixohalino de Bahía Samborombón: Conservación y Perspectivas, in Humedales Fluviales de América del Sur Hacia un manejo sustentable. Proteger, Buenos Aires, Argentina, pp. 89-106.

Watanobe, T., Ishiguro, N., Nakano, M., 2003. Phylogeography and population structure of the Japanese wild boar Sus scrofa leucomystax: mitochondrial DNA variation. Zool. Sci. 20 (12), 1477-1489, http://dx.doi.org/10.2108/zsj.20.1477.

Wernicke, E., 1938. Rutas y Etapas de la Introducción de los Animales Domésticos en las Tierras Americanas. Anales de la Sociedad Argentina de Estudios Geográficos. 6, 77-83.

Zadik, B.J., Doctoral dissertation 2005. The Iberian Pig in Spain and the Americas at the Time of Columbus. University of California, Berkeley, United States. 